\title{
Effects of Polymerized Whey Proteins Isolates on the Quality of Stirred Yoghurt made from Camel Milk
}

Hafiz Arbab Sakandar ${ }^{*}$, Muhammad Imran¹, Nuzhat Huma², Sarfraz Ahmad², Hafiz Khuram Wasim Aslam², Muhammad Azam² and Muhammad Shoaib ${ }^{2}$

${ }^{1}$ Microbiology Department, Qaid-I-Azam University, Islamabad, 44000, Pakistan

${ }^{2}$ National Institute of Food Science and Technology, University of Agriculture Faisalabad, 38000, Pakistan

\begin{abstract}
Camel milk has unique characteristics as compare to the other mammal's milks. It has anti-carcinogenic, anti-hepatic, antidiabetic and anti-hypertension bioactive components. Polymerized whey protein is important for its functional and nutritional properties in various dairy food products. This study was conducted to check the effects of polymerized whey protein isolates as thickening agent on the camel milk stirred yoghurt. $10 \% \mathrm{w} / \mathrm{v}$ polymerized whey protein isolates (PWPI) were prepared by heating whey proteins at $85^{\circ} \mathrm{C}$ for 30 minutes at $\mathrm{pH}$. Stirred yoghurt from camel milk was prepared by using PWPI as thickening agent in various concentrations of $2,4,6$ and $8 \%$ and compared with the control (without PWPI). All the samples were studied for a period of 21 days with an interval of 7 days for physico-chemical, compositional, rheological and microbial by using standard methods. Increased concentrations of PWPI have least effects on $\mathrm{pH}$ and acidity whereas $\mathrm{pH}$ decreased and acidity increased with the increase of storage days. Protein, ash and total solids increased with the increase of PWPI concentration whereas fat contents were very close to each other in all samples. There was no significant effect of storage days on all these constituents of all yoghurt samples. The viscosity of the camel milk stirred yoghurt increased with the increase of concentration of PWPI showing maximum at maximum concentration i.e. $8 \%$ and the lowest in the control. Reciprocally water holding capacity also increased and syneresis decreased with the increasing concentration of PWPI. PWPI had no effect on TPC of all samples. Results showed that PWPI can be a good source to have desired characteristics in camel milk stirred yoghurt like gelling, viscosity, less syneresis and better hydro-colloidal properties.
\end{abstract}

Keywords: Camel milk; Polymerized whey protein isolates; Rheology; Stirred yoghurt

\section{Introduction}

Different specifications and attributes are owned by camels which are also very quintessential such as they can survive in very harsh environment and in dearth of food and water due their body structure and internal setup [1]. The people which live in such environment where there is lack of sources such as water and vegetation, in such environments camel plays very vital part by providing milk, meat and used for plowing [2]. It can transfer bad quality pasture in milk, flesh and milk which are used for various benefits. They are playing a gigantic role to maintain the economy of farmers which live in precincts of poverty [3]. Camel is the most reasonable and proficient animal in the arid and semiarid range lands of Pakistan. It is observed that camels can tolerate high temperature, paltry vegetation and lack of water and camel milk is highly nutritious to fulfill the nutritional demands of new born [4]. The environmental situation and supervision of camels can increase production of milk in camels. Lactation period of camel is nine months to eighteen months on average it is twelve months. Arabian camels can produce on an average 2270 liters of milk per year and almost 3.4 to 6.4 liter of milk in a day with an average of 5.03 liter per day [5]. When reproduction ability of camels is enhanced, a great impact on the milk production from camels observed [6].

The camel milk in Saudi Arabia had 2.2 to $6.1 \%$ fat, 3.2 to $5.6 \%$ lactose and 85.5 to $89.5 \%$ moisture with specific gravity between 1.026 to 1.036 [7]. Cow, buffalo and sheep milk has higher specific gravity as compared to the camel milk. Different concentrations were observed $86.90 \%$ moisture, $5.75 \%$ fat, $5.77 \%$ lactose, $3.60 \%$ protein, $0.66 \%$ ash [8]. Turkman Sahara camel has $12.35 \%$ total solids, $2.8 \%$ protein, $4.15 \%$ fat, $4.50 \%$ lactose, $0.75 \%$ ash, $0.22 \%$ acidity and specific gravity of 1.032 [9]. It milk has queer characteristics which are much different from other mammals milk such as it has high level of insulin, vitamins and minerals i.e. Sodium, Potassium, Iron, Copper, Zinc and Magnesium.
It has very low level of carbohydrates, amino acids and cholesterol $[10,11]$. Vitamins present in camel milk have antioxidant activity and helpful in controlling tissue damage caused by harmful substances [12]. Additionally, camel milk can be stored for long time on room temperature without greater changes in quality [13]. It is very useful for those patients which are deficient in Lactose-14 because camel milk does not cause any allergic response [14]. In brief, Milk from camel has nutritional as well as medicinal value. Vitamin $\mathrm{C}$ is 4 to 11 times greater in concentration in camel as compared to bovine milk having great role in immune system of humans, providing unfavorable conditions for the growth of microbes and the best option for desert dwellers [15]. Shalash [9] observed that camel milk is good source of $\left(58.5 \mathrm{mg}^{\mathrm{kg}} \mathrm{kg}^{-1}\right)$ vitamin C and resembles with the milk of goat and cow.

Fermented milk products are utilized as food with added nutritional value and have a large growing market for dairy industry. Among these products, stirred yoghurt has greater importance for the consumers who observe the appearance and texture as reception criteria. Wheying-off, also known as syneresis is the most common fault when it is stored. The producers attempt to put off syneresis and make sure texture by increasing total solids constituents of camel milk, by the addition of milk powder and stabilizers such as starch, pectin and gelatin. In addition to these typically adopted methods to be able to

*Corresponding author: Hafiz Arbab Sakandar, Microbiology Department, Qaid-I-Azam University, Islamabad, 44000, Pakistan, Tel: 34501-8075046; E-mail: arbab_sakandar@yahoo.com

Received May 20, 2014; Accepted July 17, 2014; Published July 31, 2014

Citation: Sakandar HA, Imran M, Huma N, Ahmad S, Aslam HKW (2014) Effects of Polymerized Whey Proteins Isolates on the Quality of Stirred Yoghurt made from Camel Milk. J Food Process Technol 5: 350. doi:10.4172/2157-7110.1000350

Copyright: (c) 2014 Sakandar HA, et al. This is an open-access article distributed under the terms of the Creative Commons Attribution License, which permits unrestricted use, distribution, and reproduction in any medium, provided the original author and source are credited. 
improve texture as well as the consistency, anionic polysaccharides from the particular tissues of many fruits [10] and whey protein polymers/ isolates are also used as gelling agents in stirred yoghurt. The latter can be made by applying heat treatment. It is not only helpful to increase product safety simply by microbiologically point of view, but also useful to improve the organoleptic features regarding milk products simply by having an influence on the particular features regarding dairy protein [16]. Whey protein polymerization can result in gel creation by different necessary protein concentrations of whey. The particular inclusion regarding stabilizers for instance pectin and also improving total solids regarding dairy are usually the most frequent strategies which can be followed to boost uniformity and mouth feel of yoghurt. It is observed that yoghurt syneresis and viscosity may be better simply by addition of milk together with polymers of whey protein. Polymerized whey protein are defined as aggregates of whey protein which are soluble and developed when thermally treated at an ambient temperature and concentration of protein which usually develop a gel but do not owing to low concentration of salt [17].

The objective of study was to develop stirred yoghurt from camel milk because camel milk protein do aggregate and coagulate so curd is not developed polymerized whey protein isolates are used as thickening agent to develop curd. Texture of yoghurt is the major attribute for the consumers. Polymerized whey protein isolates interacted with casein and developed curd of camel milk.

\section{Materials and Methods}

\section{Materials}

Milk was bought from the nomads who were in the vicinity of Faisalabad, Pakistan. The starter culture which was used in the formation of stirred yoghurt from camel milk was mixed culture NESTLE YOGHURT bought from local market in Faisalabad, Pakistan which was consist of different strains of bacteria.

Whey protein isolate was bought from local market in Faisalabad, Pakistan then it was polymerized to use in camel milk stirred yoghurt.

\section{Preparation of polymerized whey proteins}

First of all solution (10\%) of whey protein isolate was prepared after that $0.1 \mathrm{M} \mathrm{NaOH}$ was added to adjust the $\mathrm{pH}$ of solution at 7 when required $\mathrm{pH}$ was obtained then solution was heated at $85^{\circ} \mathrm{C}$ for 30 minutes after that polymerized whey protein was obtained which was gel like then was stored at room temperature. Then it was used as a thickening agent in camel milk stirred yoghurt drink with different concentrations.

\section{Preparation of yoghurt}

First of all fresh camel milk was taken in aseptic apparatus. Then it was heated at $65^{\circ} \mathrm{C}$ for 42 minutes after that it was homogenized then again heated at $85^{\circ} \mathrm{C}$ for 30 minutes it is done to eliminate any contamination. It is cooled in ice bath to reduce the temperature for inoculation then it was incubated for four and half hour at $42^{\circ} \mathrm{C}$. At the end it was stored at $6-7^{\circ} \mathrm{C}$ for analysis and storage study.

\section{Preliminary trials with various concentrations of PWP}

Various concentrations of polymerized whey protein were used to demonstrate the quality of stirred camel milk yoghurt which is given in Table 1. Five samples were prepared with different concentrations of polymerized whey protein. Control sample has no polymerized whey protein while other four has various concentrations of polymerized

\begin{tabular}{|c|c|}
\hline Sample & \%PWP \\
\hline $\mathrm{T}_{0}$ & - \\
\hline $\mathrm{T}_{1}$ & 2 \\
\hline $\mathrm{T}_{2}$ & 4 \\
\hline $\mathrm{T}_{3}$ & 6 \\
\hline $\mathrm{T}_{4}$ & 8 \\
\hline
\end{tabular}

Table 1: Concentrations of PWP.

whey protein. Sample $1,2,3,4$ has $2 \%, 4 \%, 6 \%, 8 \%$ polymerized whey protein respectively. Different treatments were analyzed for impact on viscosity, syneresis and other parameters

Syneresis of camel milk stirred yoghurts with PWP content of 0 , $2 \%, 4 \%, 6 \%, 8 \%,(\%, w / w)$ was determined. Ten (10) gram of each yogurt sample was put on a filter paper placing on the upper of a funnel. After 10 minute of drainage in vacuum condition, the amount of rest stirred yoghurt made from camel milk was measured and syneresis was calculated as follow:

Free whey $(g / 100 \mathrm{~g})=$ Weight of initial sample - weight of sample after filtration /Weight of initial sample ${ }^{\star} 100$

\section{Chemical analysis}

The stirred camel milk yoghurt was analyzed for total solids, acidity, fat, protein, ash and moisture by using standard method [18]. Acidity was determined by titrating it with $0.1 \mathrm{NaOH}$, fat was determined by Gerber method, protein was determined by Kjeldhal method by using 6.38 factor and ash was determined by muffle furnace [18].

\section{Statistical analysis}

Results were analyzed by using 2 way repeated Complete Randomized Block and by ANOVA.

\section{Results and Discussion}

\section{Preliminary trials results}

Effect on viscosity: The viscosity of stirred yoghurt made from the camel milk with different concentrations of polymerized whey proteins was analyzed. Viscosity of stirred yoghurt was measured by Food Texture Puff Device (FPD) Rotational rheometry experiments were performed with an AR1000-N rheometer supplied with a 545006.901 DIN conical concentric cylinder (TA Instruments, USA). The inner and outer cylinders have a radius of 14 and $15 \mathrm{~mm}$, respectively, and the gap at the bottom has a height of $5920 \mu \mathrm{m}$. The sample was loaded by means of a $30 \mathrm{ml}$ syringe (BD Plastipak, Ireland). To minimize the damage of the sample's structure, the narrow part of the syringe was removed and this modified syringe was calibrated for a sample volume of $20 \mathrm{ml}$. The sample was subject to a constant shear rate $\left(64 \mathrm{~s}^{-1}\right)$ for 10 seconds. The temperature during these measurements was kept constant at $10^{\circ} \mathrm{C}$. The apparent viscosity at 10 seconds was the reference value used in this study. Results showed that the stirred yoghurt sample with 0 percent polymerized whey protein has least viscosity while the sample with $8 \%$ polymerized whey protein has maximum viscosity as compared to $2 \%, 4 \%$ and $6 \%$ polymerized whey protein and with storage time it was increased in every treatment. Viscosity of yoghurt has a direct relation with the thickness of yogurt (Figure 1).

Viscosities of different samples is given in the chart it is vividly seen 
Citation: Sakandar HA, Imran M, Huma N, Ahmad S, Aslam HKW (2014) Effects of Polymerized Whey Proteins Isolates on the Quality of Stirred Yoghurt made from Camel Milk. J Food Process Technol 5: 350. doi:10.4172/2157-7110.1000350

Page 3 of 5

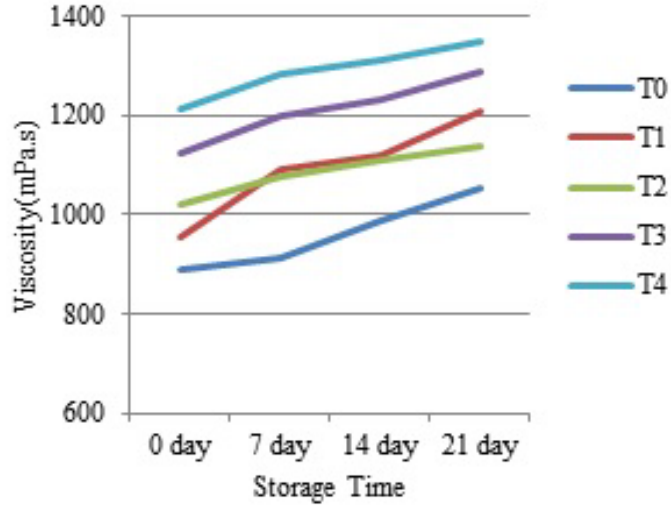

Figure 1: Effect of polymerized whey proteins on viscosity.

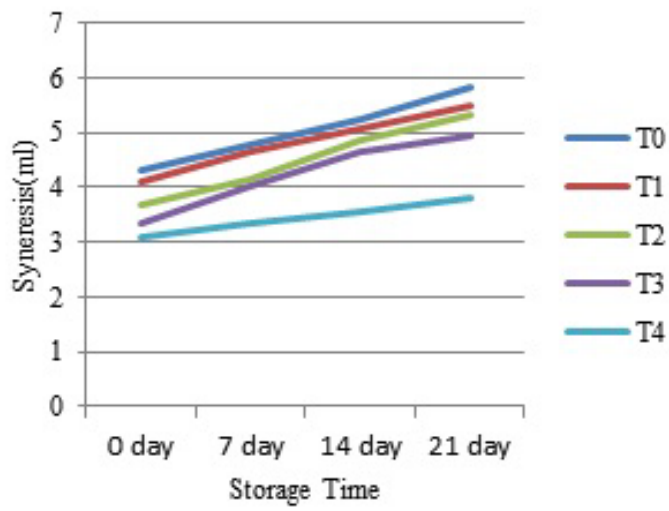

Figure 2: Effect on Syneresis.

that the sample with no polymerized whey protein has lowest viscosity while the sample with $8 \%$ polymerized whey protein has highest viscosity the viscosity is in centipoises.

\section{Syneresis}

Syneresis or wheying-off is expulsion of whey from yoghurt which comes on the surface. Syneresis is the situation in which the yogurt gel is shrinked and the whey is expelled and released whey water was separated from the yoghurt. The syneresis was expressed as volume per $\mathrm{ml}$ of the whey water separated from the yoghurt. Syneresis is the main problem during the storage of yoghurt and negatively effects the consumer perception (Figure 2).

The sample with no polymerized whey protein has shown little greater syneresis as compare to samples with polymerized whey protein and sample with $8 \%$ polymerized whey protein showed most low syneresis as compared to $2 \%, 4 \%$ and $6 \%$.

In chart it is shown that control has highest syneresis as compare to others which have polymerized whey proteins. While in other samples which have polymerized whey proteins the sample with $8 \%$ polymerized whey protein has lowest syneresis.

\section{Effect on water holding capacity}

The water holding capacity for the yoghurt is its ability to retain water into the curd. Polymerized whey protein showed significant difference on water holding capacity. As the concentration of polymerized whey protein was $T_{0}$ had minimum water holding capacity and $T_{4}$ had maximum water holding capacity. Storage had negative impact on water holding capacity of yoghurt, $\mathrm{T}_{2}$ showed maximum decrease with storage and $\mathrm{T}_{4}$ had minimum decline (Figure 3 ).

$$
W H C=\frac{(Y-W E) * 100}{Y}
$$

\section{Effect on acidity}

The acidity was determined by direct titration (AOAC 2000) by the following formula.

Increased water holding capacity was increased of yoghurt.

$$
\text { Acidity } \%=\frac{0.009 \times \text { vol.of } \mathrm{N} / 10 \mathrm{NaOH} \text { used }(\mathrm{ml}) \times 100}{\text { Wt.of Sample }(\mathrm{g})}
$$

Acidity of stirred yoghurt was increased as the time passed but there was no significant difference among the acidity of treatments so polymerized whey protein had no effect on the acidity of stirred yoghurt. But $\mathrm{T}_{0}$ had maximum acidity and $\mathrm{T}_{3}$ had minimum with respect to other treatments (Figure 4).

\section{Effect on $\mathbf{p H}$}

The $\mathrm{pH}$ of yoghurt samples were measured with a $\mathrm{pH}$ meter (Wellian model-Inolab $\mathrm{pH} 720$, WTW 82362) by following the method of AOAC (2000). There was no significant difference of polymerized whey protein on the $\mathrm{pH}$ of stirred yoghurt. $\mathrm{T}_{0}$ had maximum decline in

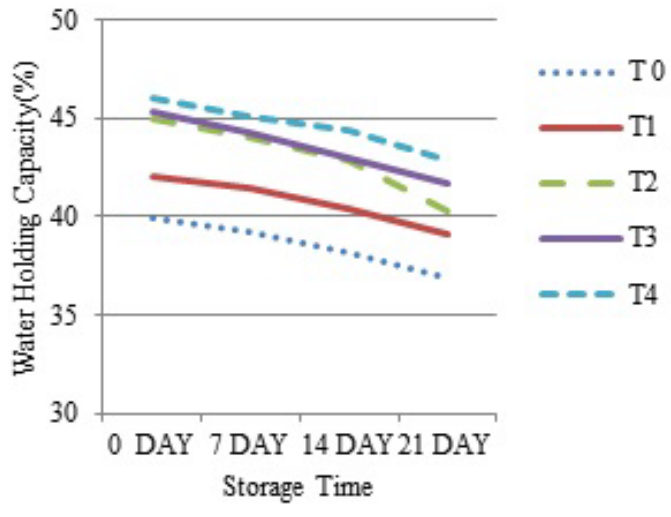

Figure 3: Effect on Water Holding Capacity.

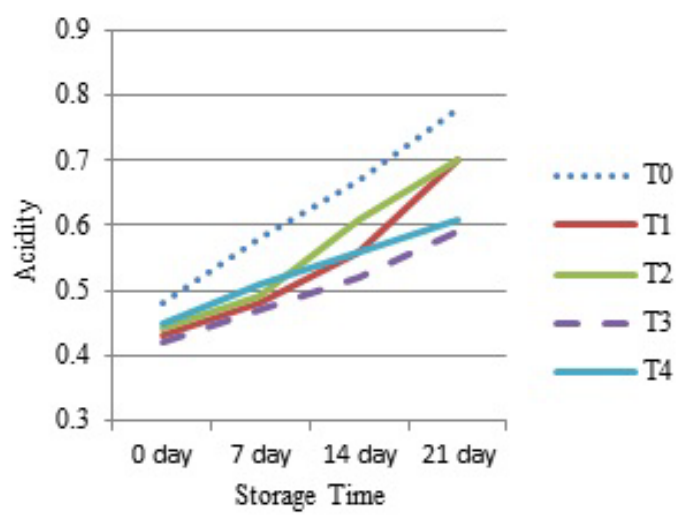

Figure 4: Effect on Acidity. 
Citation: Sakandar HA, Imran M, Huma N, Ahmad S, Aslam HKW (2014) Effects of Polymerized Whey Proteins Isolates on the Quality of Stirred Yoghurt made from Camel Milk. J Food Process Technol 5: 350. doi:10.4172/2157-7110.1000350

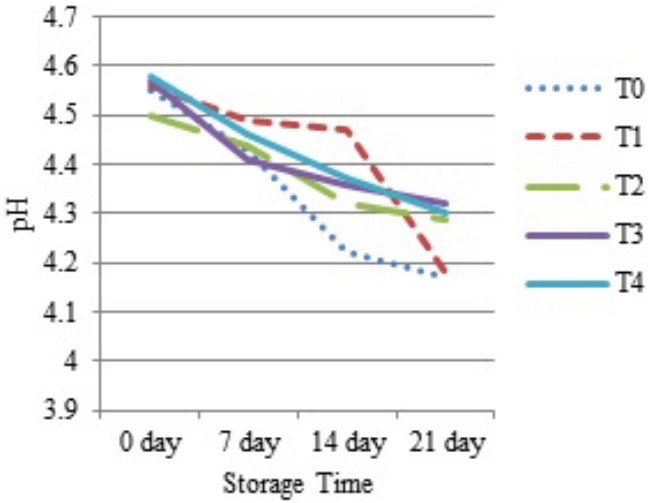

Figure 5: Effect on $\mathrm{Ph}$.

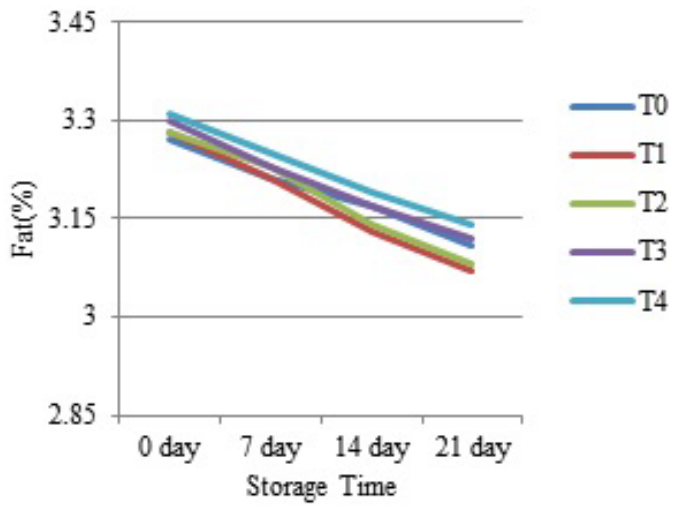

Figure 6: Effect on Fat.

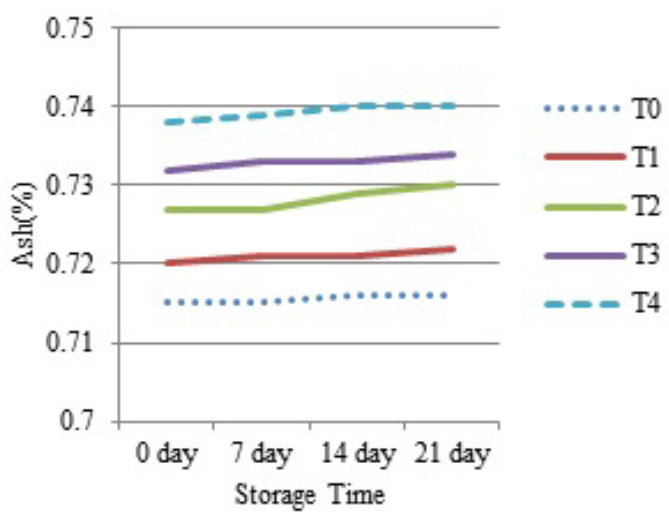

Figure 7: Effect on Ash.

$\mathrm{pH}$ whereas $\mathrm{T}_{3}$ had minimum decreases in $\mathrm{pH} . \mathrm{T}_{2}$, and $\mathrm{T}_{4}$ has smooth decline in $\mathrm{pH}$. $\mathrm{T}_{1}$ had smooth decline in $\mathrm{pH}$ up to 14 days then rapid decline was observed on 21 day (Figure 5).

\section{Effect on fat}

During storage time fat content was decreased and no significant effect was observed among the treatments all have same decline in fat content (Figure 6).

\section{Effect on ash}

There was no significant difference of storage time on ash content but it was increased as the concentration of polymerized whey protein was increased $\mathrm{T}_{4}$ has maximum ash content while $\mathrm{T}_{0}$ has minimum among the treatments (Figure 7).

\section{Effect on total plate count}

It was observed that polymerized whey protein had no significant effect on total plate count. But it was decreases with storage time as the acidity decreases and $\mathrm{pH}$ increases so conditions become unfavorable for the microbes.

\section{Conclusions}

Polymerized whey protein proved to be a suitable thickening agent for camel milk stirred yoghurt to enhance viscosity and syneresis. The optimal concentration of PWP was $8 \%$ which showed good sensory attributes. The total plate count was not affected by the polymerized whey protein it was about $10^{6} \mathrm{cfu}$ per $\mathrm{ml}$ over the 3 weeks of storage and bio coliforms were observed. Results from this study revealed that polymerized whey protein as a stabilizer may be useful to improve the syneresis, water holding capacity and viscosity. It was also observed that it had no significant effect on the $\mathrm{pH}$ and acidity while protein, ash and total solids were increased.

\section{References}

1. Williamson G, Payne WTA (1978) An Introduction to Animal Husbandry in the Tropics, London.

2. Bhakat C, Sahani MS (2001) Impact of camel production system on the sustainability of marginal farmers in hot arid villages of Thar desert. Indian J Anim Res 35: 10-14.

3. Tegegn T (1989) Camel pastoralism as food system in Ethiopia. Proceedings of the IDRC/O; CA workshop in April, 1989. IDR, AAU in cooperation with SIAS, Uppsala.

4. Al-Eknah MM (2000) Reproduction in Old World camels. Anim Reprod Sci 6061: $583-592$

5. Yagil R, Etzion Z, Ganani J (1979) Camel thyroid metabolism: The effect of season and dehydration. J App Physiol 45: 540-544.

6. Faye B (2005) Productivity potential of camels. Proc. of Intern. Workshop. Desertification Combat and Food Safety. The added value of camel producers. Ashkabad (Turkmenistqan), 19-22 April, 2004. NATO science Series, I: Life and Behavioral Sciences. IOS Press Publ, Amsterdam (The Netherlands).

7. Getachew F (2003) Milk and dairy products, post-harvest losses and food safety in sub- Saharan Africa and the Near East. Assessments Report on the Dairy Sub-sector in Ethiopia. Action Programme for the Prevention of Food Losses, FAO, Rome.

8. El-Erian AFM (1979) Studies on camel milk in the Kingdom of Saudi Arabia Proc. 2nd Arab Conf. Food Sci. Technol., Saudi Arabia.

9. Shalash MR (1979) Utilization of camel meat and milk in human nourishment. In IFS-Symposium on Camels.' Sudan.

10. Karim G, Gooklani I (1987) Studies on the gross components of camel milk in Turkman Sahara. 1. Vet. Faculty, Tehran, Iran.

11. Kazmierski ML, Wicker, Corredig M (2003) Interactions of b-lactoglobulin and high-methoxylpectins in acidified systems. J of Food Sci 68: 1673-1679.

12. Al-Hashem $F$ (2009) Camel milk protects against aluminium chloride-induced toxicity in the liver and kidney of white albino rats. Am. J Biochem Biotechnol 5: $98-108$.

13. Humaid Al, Mousa HM, El-Mergawi RA, Abdel-salam AM (2010) Chemical composition and antioxidant activity of dates and dates-camel-milk mixtures as a protective meal against lipid peroxidation activity in rats. J Food Technol 5: 22-30.

14. Brans G, Schroe"n CGPH, Van der Sman RGM, Boom RM (2004) Membrane 
Citation: Sakandar HA, Imran M, Huma N, Ahmad S, Aslam HKW (2014) Effects of Polymerized Whey Proteins Isolates on the Quality of Stirred Yoghurt made from Camel Milk. J Food Process Technol 5: 350. doi:10.4172/2157-7110.1000350

Page 5 of 5

fractionation of milk: state of the art and challenges. J Membrane Sci 243: 263272

15. Sohail MA (1983) The role of the Arabian camel (Camelusdromedarius) in animal production. World Rev Anim Prod 19: 38-40.

16. Li JC, Guo MR (2006) Effects of polymerized whey proteins on consistency and water-holding properties of goat's milk yogurt. J Food Sci 71: 34-C38.
17. Vardhanabhuti B, Foegeding EA, McGuffy MK, Daubert CR, Swaisgood HE (2001) Gelation properties of dispersions containing polymerized and native whey protein isolate. Food Hydrocolloids 15: 165-175.

18. AOAC (2000) Association of Official Analytical Chemists. Official methods of analysis. (17thedn) published by AOAC. Po box 540. Benjamin Franklin station, Washington, DC, USA 